Brazilian Journal

of Chemical

ISSN 0104-6632

Engineering

\title{
EVALUATION OF DISTILLATION CURVES FOR BIO-OIL OBTAINED FROM THERMAL CRACKING OF WASTE COOKING OIL
}

\author{
T. Stedile', R. F. Beims ${ }^{1}$, L. Ender ${ }^{1}$, D. R. Scharf ${ }^{2}$, \\ E. L. Simionatto ${ }^{2}$, H. F. Meier ${ }^{1}$ and V. R. Wiggers ${ }^{1 *}$ \\ ${ }^{1}$ Universidade de Blumenau, Departamento de Engenharia Química, Blumenau, SC, Brasil. \\ ORCID: 0000-0003-0169-9549; E-mail: vwiggers@furb.br, ORCID: 0000-0003-2273-8025 \\ ${ }^{2}$ Universidade de Blumenau, Departamento de Química, Blumenau, SC, Brasil.
}

(Submitted: September 1, 2017 ; Revised: November 17, 2017 ; Accepted: February 15, 2018)

\begin{abstract}
Bio-oil obtained from thermal cracking of waste cooking oil (WCO) is a complex mixture of different chemical compounds and, like crude oil, it is composed mainly of hydrocarbons. The large number of compounds in bio-oil leads to complex and expensive methods for its properties determination. In this study, the distillation curves were constructed for samples of bio-oils obtained from the thermal cracking of WCO in order to predict the properties (such as molecular weight, viscosity and refractive index). Although it is not often employed for bio-oil analyses, the distillation curve method is commonly used in the petroleum industry. Atmospheric and vacuum distillations were performed according to ASTM D86 and ASTM D1160 standards, respectively, for six samples of bio-oil and one sample of crude oil. The results were converted to true boiling point (ASTM D2892) according to the API method (1997) and common petroleum refining correlations were employed. The estimated values for the properties showed little deviation in relation to the experimental data. The bio-oil and crude oil samples contained heavy compounds in their composition, and all samples studied are considered as heavy oils considering the ${ }^{\circ} \mathrm{API}$ range.

Keywords: Bio-oil; Oil; Biofuels; Bio-refinery; Physical properties; Pyrolysis; Co-processing.
\end{abstract}

\section{INTRODUCTION}

Petroleum, also referred to as oil or crude oil, is a complex mixture of hydrocarbons that can be classified into three main types of compounds: paraffins, naphthenes and aromatics. These hydrocarbons can contain heteroatoms, such as sulfur, nitrogen, oxygen and metals (Wauquier, 1995; Fahim et al., 2010; Speight, 2006; Behrenbruch and Dedigama, 2007; Quelhas et al., 2014). Currently, petroleum is the main source material for the production of fuels, yet there are several concerns related to its usage, due to its declining availability and environmental issues (e.g., greenhouse gases). Hence, research on renewable and sustainable sources to reduce our reliance on fossil fuels has been steadily increasing (Zhang and $\mathrm{Xu}$, 2010; Bielansky et al., 2011; Cardoso et al., 2011; Dai et al., 2015; Gaurav et al., 2017). In this regard, the use of biomass instead of petroleum to produce liquid fuels seems promising, since this is considered to be a renewable energy source (Ho et al., 2014; Junming et al., 2016).

Several biomass conversion methods have been reported in the literature and thermochemical processes appear to be efficient for transforming biomass into valuable products such as biogas (non-condensable fraction), bio-oil (or other liquid fraction with fuel characteristics) and coke (undesirable or as a co-product) (Yang et al., 2013). Specially for a feedstock like waste cooking oil (WCO), the hydrotreating process is often

\footnotetext{
* Corresponding author: V. R. Wiggers - E-mail: vwiggers@furb.br
} 
employed and several studies demonstrated it to be an effective option for removing oxygenates from the biomass aiming at biodiesel production (Bezergianni et al., 2010; Bezergianni et al., 2011; Bezergianni et al., 2012; Bergthorson and Thomson, 2015). However, the $\mathrm{H}_{2}$ requirement may make hydrotreating usually more expensive than other routes (Huber and Corma, 2007). Another thermochemical processes available is thermal cracking (also called pyrolysis). Thermal cracking involves the thermal decomposition of biomass by heat in the absence of oxygen and, in some cases, in the presence of a catalyst (Jayasinghe and Hawboldt, 2012; Goyal et al., 2008; Naik et al., 2010). Thermal cracking provides high yields of a liquid fraction similar to crude oil, when optimal operational conditions are applied (Wiggers et al., 2013).

Bio-oil is a complex mixture of oxygenated compounds, aliphatic hydrocarbons, and aromatics (Bridgwater, 2012; Xiu and Shahbazi, 2012; Zhang et al., 2013). The type of biomass used plays an important role in relation to the properties of the bio-oil obtained and it can be divided into two main groups according to the source: lignocellulose (LC) and triglyceride (TG). TG biomass has been the focus of several studies due to its similarity with fossil fuels. Bio-oil produced from TG source is composed mainly of hydrocarbons and contains less oxygenated compounds than bio-oil produced from lignocellulose (Wiggers et al., 2017; Stedile et al., 2015; Doronin et al., 2016). TG sources comprise lipid biomass, such as vegetable oils and animal fats, and have been successfully reported in the literature aiming at their thermochemical conversion to bio-oil. Oil type plays an important role in bio-oil characteristics, as demonstrated by Buzetzki et al. (2011). Therefore, studies can be found with several different vegetable oil sources, such as palm oil (Mancio et al., 2016), waste fish oil (Wiggers et al., 2009a), soybean oil (Wiggers et al., 2009b), waste cooking oil (Junming et al., 2011; Meier et al., 2015; Periyasamy, 2015), hydrogenated fat (Beims et al., 2018a; Beims et al., 2018b) and rubber seed oil (Lu et al., 2014). In addition, some studies have investigated the conversion of isolated free fatty acids, aiming to increase liquid product yields (Asomaning et al., 2012; Asomaning et al., 2014).

Nevertheless, the determination of the physical and chemical properties of bio-oil is usually complex and expensive due to the large number of different compounds, which leads to barriers in the industrial application of thermal cracking (Butler et al., 2011). The determination of bio-oil properties is necessary to provide enough data to propose satisfactory kinetic mechanisms for the thermal cracking reaction, which may provide information on the operating conditions aiming at process development and scaling up studies (Wiggers et al., 2017) as well as investigations on co-processing operations with crude oil in a standard refinery plant (Beims et al., 2017). Hence, constructing the distillation curve could address these issues, since it is a key method for gathering information on complex mixtures such as bio-oil and petroleum. With the fluid's volatility measurement, it is possible to model and predict the thermodynamic properties of complex mixtures (Harries et al., 2017).

The distillation curve method consists of plotting the boiling temperature versus the distilled volume fraction of a liquid mixture (Ott et al., 2008a; Ott et al., 2008b; Bruno et al., 2010; Cheng et al., 2014) and it has long been employed to predict properties for crude oil characterization. Properties worth mentioning are (Fahim, 2012):

- $\quad$ volumetric average boiling point (VABP) and mean average boiling point (MeABP), which are ways of representing the median boiling point of a petroleum sample; VABP and MeABP of different crude oils may have a wide range (i.e. from 150 to $350^{\circ} \mathrm{C}$ ). A mixture of different compounds boils over a certain range of temperature, reflecting the boiling point of each specific compound present in the mixture. Therefore, lower values suggest lighter crude oils, whereas higher values are expected for heavier oils;

- Watson characterization factor $(\mathrm{Kw})$, which comprises a classification method according to the variety of paraffinic, naphthenic, intermediate or aromatic in the crude oil. Typical ranges of $\mathrm{Kw}$ are between 10 to 13. A characterization factor of 12.5 or greater implies a hydrocarbon compound predominantly paraffinic in nature. Lower values of this factor suggest hydrocarbons with more naphthenic or aromatic components. Highly aromatic hydrocarbons demonstrate values of 10.0 or less;

- $\quad$ refractive index $(\mathrm{RI})$, an input parameter for other correlations within the refinery process;

- $\quad$ kinematic viscosity;

- molecular weight (MW) of petroleum fractions is usually estimated, since crude oil is comprised of a complex mixture of hydrocarbons. MW ranges from 70 to 200 in lighter fractions and between 200 to 600 in heavier fractions.

Standard methods are available for distillation tests on crude oil or petroleum fractions (Fahim, 2012; Ott et al., 2008b), and they can also be used for establishing specifications for complex fluids (Ott et al., 2008b; Bruno et al., 2010). In this context, ASTM D86 is widely applied. This procedure is carried out at atmospheric pressure and used to obtain information on gasoline, naphtha, kerosene, gas-oils, and other similar petroleum fractions. Regarding the heavy petroleum fractions, ASTM D1160 is commonly used. This is performed at lower pressures ( 1 and 50 $\mathrm{mmHg}$ ) and the temperatures obtained are converted according to ASTM D86 (API, 1997). The data 
obtained using ASTM D86 can be converted to true boiling point (TBP) temperatures (ASTM D2892), this being a reliable tool for the characterization of crude oil fractions. However, since the TBP method is expensive and time consuming, the conversion of values obtained with ASTM D86 to TBP offers a faster approach with acceptable results (Fahim, 2012).

Several works in the literature (Lima et al., 2004; Lu et al., 2014; Shirazi et al., 2016) deal with TG's bio-oil production. However, in general, the quantity of bio-oil obtained is not sufficient to apply the ASTM D86 method. In this study, the properties of bio-oil samples produced from the thermal cracking of waste cooking oil were predicted using distillation curves and correlations commonly employed to characterize crude oil and its fractions. Other properties evaluated were density, molecular weight, kinematic viscosity, API gravity, volumetric average boiling point (VAPB), Watson characterization factor, refractive index, iodine index and acid index. A chromatographic analysis of all samples was also performed to determine the distribution of compounds according to the number of carbon atoms in the molecular chain. The aim of this research was to apply the distillation curve in the characterization of bio-oil, based on a well-known method used in the petroleum industry. This could be an important support tool for bio-oil co-processing (Wiggers et al., 2017; Beims et al., 2017), process simulation and the design and scale-up of operations.

\section{MATERIALS AND METHODS}

\section{Materials}

The bio-oil samples used in this study were obtained from the thermal cracking of waste cooking oil as described in a previous publication (Frainer et al., 2014). The experiments were conducted in a continuous bench-scale reactor (Botton et al., 2012; Botton et al., 2016) under isothermal and steady-state conditions, producing around $300 \mathrm{~g}$ of bio-oil in each run. The cracking temperature was $550^{\circ} \mathrm{C}$ and the residence time in the reactor was varied, as shown in Table 1. For comparison purposes, tests were also performed on a petroleum crude oil sample originating

Table 1. Operating conditions used in the thermal cracking process.

\begin{tabular}{ccc}
\hline \multirow{2}{*}{ Sample } & $\begin{array}{c}\text { Input flow } \\
(\mathbf{g} / \mathbf{h})\end{array}$ & $\begin{array}{c}\text { Residence time } \\
(\mathbf{s}) *\end{array}$ \\
\hline a & 125 & 12.5 \\
b & 218 & 8.2 \\
c & 278 & 6.8 \\
d & 348 & 5.3 \\
e & 420 & 4.5 \\
f & 496 & 4.2 \\
\hline
\end{tabular}

* Estimated as an ideal gas as a function of temperature and average molecular weight. from the Bauna oil field (Brazil). Petroleum properties and characteristics may vary in a wide range according to the extraction locations; therefore, it is difficult to establish a confidence range. A comparison to a specific sample brings an estimation of how close to a petroleum sample the bio-oils samples might be, although it must be considered that different crudes have different properties.

\section{Distillation Curves And Predicted Properties}

The distillation curves were obtained using an automatic vacuum distiller (B/R Instrument, model M690), which registers the distilled volume, temperature and the first drop. The experiment was carried out until the bio-oil temperature reached $400^{\circ} \mathrm{C}$ according to ASTM D86-04b. Vacuum distillation was then performed with the remaining bio-oil until $400^{\circ} \mathrm{C}$ was reached according to ASTM D1160-02a and to avoid undesired cracking of the bio-oil. Data provided by ASTM D1160-02a (boiling temperatures at sub-atmospheric pressure) were converted to ASTM D86-04b (normal boiling point - NBP) using the procedure 5A1.13 from API - TDB (API, 1993). Minor modifications were applied to both standards, consisting of a distillation rate of $1 \mathrm{ml} / \mathrm{min}$ (instead of 4-5 $\mathrm{ml} / \mathrm{min}$ ) and $200 \mathrm{ml}$ of sample was used (instead of $100 \mathrm{ml}$ ).

The data obtained applying the ASTM D86 distillation method allow the evaluation of bio-oil properties. It is a common procedure to convert the results obtained with ASTM D86 to the true boiling point (TBP), by means of the API Method (API, 1997) or the Riazi and Daubert Method (Wauquier, 1995). TBP distillation provides more accurate characterization of the volatility of crude oil. However, it is an exhaustive and time-consuming method. Thus, the conversion of ASTM into TBP allows gathering precise data with less effort.

Based on the TBP distillation data it is possible to calculate the volumetric average boiling point (VABP) of the sample with Equation 1, as well as the mean average boiling point (MeABP), using Equation 2.

$\mathrm{VABP}=\frac{\mathrm{T}_{10}+\mathrm{T}_{30}+\mathrm{T}_{50}+\mathrm{T}_{70}+\mathrm{T}_{90}}{5}$

$\mathrm{MeABP}=\mathrm{VABP}+\Delta$

where $\mathrm{T}$ is the temperature $\left({ }^{\circ} \mathrm{C}\right)$ in the volume distilled (subscript value) and $\Delta$ is given by Equation 3 .

$$
\begin{aligned}
\ln \Delta & =-0.94402-0.00865(\mathrm{VABP}-32)^{0.6667}+ \\
& +\left(2.99791\left(\frac{\mathrm{T}_{90}-\mathrm{T}_{10}}{90-10}\right)\right)^{0.333}
\end{aligned}
$$


Given the MeABP, the Watson characterization factor $(\mathrm{Kw})$ can be calculated using the Watson method (Fahim, 2012), Equation 4.

$$
\mathrm{K}_{\mathrm{w}}=\frac{(\mathrm{MeABP})^{1 / 3}}{\mathrm{SG}}
$$

where SG is the specific gravity, which is experimentally measured.

As crude oil is a mixture of several hydrocarbons, some properties derived from distillation curves are commonly given by empirical correlations. In this manner, an estimation of the molecular weight (MW) is given by the Pedersen correlation (Pedersen et al., 1989), Equation 5 , kinematic viscosity at $100^{\circ} \mathrm{F}\left(\mathrm{v}_{100}\right)\left(37.8^{\circ} \mathrm{C}\right)$ is given by the Abbot correlation (Abbot et al.,1971), Equation 6, and, refractive index (RI) is given by the Riazi \& Daubert method (API, 1997), Equation 7.

$$
\begin{aligned}
\mathrm{MW} & =42.965 \mathrm{exp}\left(2.097 \times 10^{-4} \mathrm{MeABP}-7.78712 \mathrm{SG}+\right. \\
& \left.+2.08476 \times 10^{-3} \mathrm{MeABP} \mathrm{SG}\right) \mathrm{MeABP}^{1.26007} \mathrm{SG}^{4.98308} \\
\log v_{100} & =4.39371-1.94733 \mathrm{~K}+0.127690 \mathrm{~K}_{\mathrm{W}}^{2}+ \\
& +3.2629 \times 10^{-4}(\mathrm{API})^{2}-1.18246 \times 10^{-2} \mathrm{~K}_{\mathrm{W}}(\mathrm{API})+ \\
& +\left[\left(0.171617 \mathrm{~K}_{\mathrm{W}}^{2}+10.9943(\mathrm{API})+9.50663 \times 10^{-2}(\mathrm{API})^{2}-\right.\right. \\
& \left.-0.860218 \mathrm{~K}(\mathrm{API})) /\left(\mathrm{API}+50.3642-4.78231 \mathrm{~K}_{\mathrm{W}}\right)\right]
\end{aligned}
$$

$\mathrm{RI}=\left(\frac{1+2 \mathrm{I}}{1-\mathrm{I}}\right)^{1 / 2}$

where I is the Huang characterization parameter at 20 ${ }^{\circ} \mathrm{C}$ and is given by Equation 8 .

$$
\begin{aligned}
\mathrm{I} & =\mathrm{a}[\exp (\mathrm{b}(\mathrm{Me} A B P)+\mathrm{c}(\mathrm{SG})+ \\
& +\mathrm{d}(\mathrm{MeABP})(\mathrm{SG}))](\mathrm{MeABP})^{\mathrm{e}}(\mathrm{SG})^{\mathrm{f}}
\end{aligned}
$$

and $\mathrm{a}, \mathrm{b}, \mathrm{c}, \mathrm{d}, \mathrm{e}$ and $\mathrm{f}$ are constants according to Table 2 (Fahim, 2012).

Table 2. Constants for the Huang characterization parameter.

\begin{tabular}{ccc}
\hline Constant & $\begin{array}{c}\text { Light } \\
\text { fraction }^{\mathbf{1}}\end{array}$ & $\begin{array}{c}\text { Heavy } \\
\text { fraction }^{2}\end{array}$ \\
\hline $\mathrm{a}$ & $2.266 \mathrm{E}-2$ & $2.341 \mathrm{E}-2$ \\
$\mathrm{~b}$ & $3.905 \mathrm{E}-4$ & $6.464 \mathrm{E}-4$ \\
$\mathrm{c}$ & 2.468 & 5.144 \\
$\mathrm{~d}$ & $-5.704 \mathrm{E}-4$ & $-3.289 \mathrm{E}-4$ \\
$\mathrm{e}$ & $5.72 \mathrm{E}-2$ & $4.07 \mathrm{E}-1$ \\
$\mathrm{f}$ & $7.20 \mathrm{E}-1$ & -3.333 \\
\hline
\end{tabular}

${ }^{1}$ Petroleum cut with MW of 70-300 and boiling point range $\left({ }^{\circ} \mathrm{F}\right)$ of 90-650. ${ }^{2}$ Petroleum cut with MW of 300-600 and boiling point range $\left({ }^{\circ} \mathrm{F}\right)$ of $650-1000$. Source: Fahim (2012).
In many cases, process simulation software is used in the characterization of crude oil, with several commercial options being available. In order to compare the data obtained from literature correlations, UNISIM software (licensed by Honeywell Process Solutions) was used for the $\mathrm{K}_{\mathrm{w}}$ (Abbot correlation (Quelhas et al., 2014)), kinematic viscosity (v) (Twu correlation (Twu, 1986) and MW estimation (Twu, 1984), using the correlations given in Equations 9, 10 and 11 , respectively.

$\mathrm{K}_{\mathrm{w}}=\frac{\mathrm{VABP}^{1 / 3}}{\mathrm{SG}}$

$v=v^{\mathrm{r} 1}\left(\frac{v^{\mathrm{r} 2}}{v^{\mathrm{r} 1}}\right)^{(1 / 2)\left(\mathrm{K}_{\mathrm{w}}-10\right)}$

$\mathrm{MW}=\frac{\mathrm{T}_{\mathrm{b}}}{\left(10.44-0.0052 \mathrm{~T}_{\mathrm{b}}\right)}$

where the superscripts $\mathrm{r} 1$ and $\mathrm{r} 2$ refer to reference fluids and $\mathrm{Tb}$ is the normal boiling point temperature, given by Equation 12 and 13 .

$$
\mathrm{T}_{\mathrm{b}}=\exp \left(\frac{5.71419+2.71579 \ln (\mathrm{MW})-0.286590 \theta^{2}-39.8544}{\ln (\mathrm{MW})-\frac{0.122488}{\ln (\mathrm{MW})^{2}}}\right)-
$$

$\theta=\ln \mathrm{MW}$

\section{Measured Properties}

Properties such as specific gravity, kinematic viscosity and refractive indexes were determined by measurable laboratory tests, according to specific standards. Specific gravity (SG) follows ASTM D5355-95 (2012). Kinematic viscosity (v) was determined according to ASTM D445 (2006) and ASTM D446 (2012). Refractive index (RI) follows ASTM D1218. API gravity is a relation with specific gravity, determined by Equation 14 (Fahim, 2012).

$$
\mathrm{API}=\frac{141.5}{\mathrm{SG}}-131.5
$$

Since they are not addressed in the distillation curve, acid index and iodine index were measured only by experimental analyses, following ASTM D 974 and EN 14111 (2003), respectively. These are important properties regarding liquid fuels, since they are associated with bio-oil corrosivity and instability. Therefore, minimum values of both are desired. In 
addition, bio-oil density was also not addressed in the distillation curve and was evaluated according to ASTM D 4052.

All analyses were repeated in triplicate, ensuring minimal uncertainties and reproducibility. The standard deviation of each analysis is presented in the corresponding tables and figures.

All samples were also submitted to gas chromatography (GC-FID) in order to determine the distribution range of the compounds according to the number of carbon atoms in the molecular chain. GCFID was performed on a Shimadzu instrument (GC2010) equipped with a RTX-1 capillary column (30 $\mathrm{m}$ $3.00 \mu \mathrm{m} \times 0.32 \mathrm{~mm}$ I.D.), using helium as the carrier gas. The injector temperature was $250^{\circ} \mathrm{C}$ and the detector temperature was $280^{\circ} \mathrm{C}$. The injection volume was 1 $\mu \mathrm{L}$. The compounds were identified by comparison of their retention times with those of n-alkane standards (from $\mathrm{C}_{8}$ to $\mathrm{C}_{19}$ ). With the data provided by GC-FID, MW was estimated using Equation 15.

$$
\mathrm{MW}=\frac{\sum[(\mathrm{CN})(\mathrm{AMW})]}{\mathrm{N}}
$$
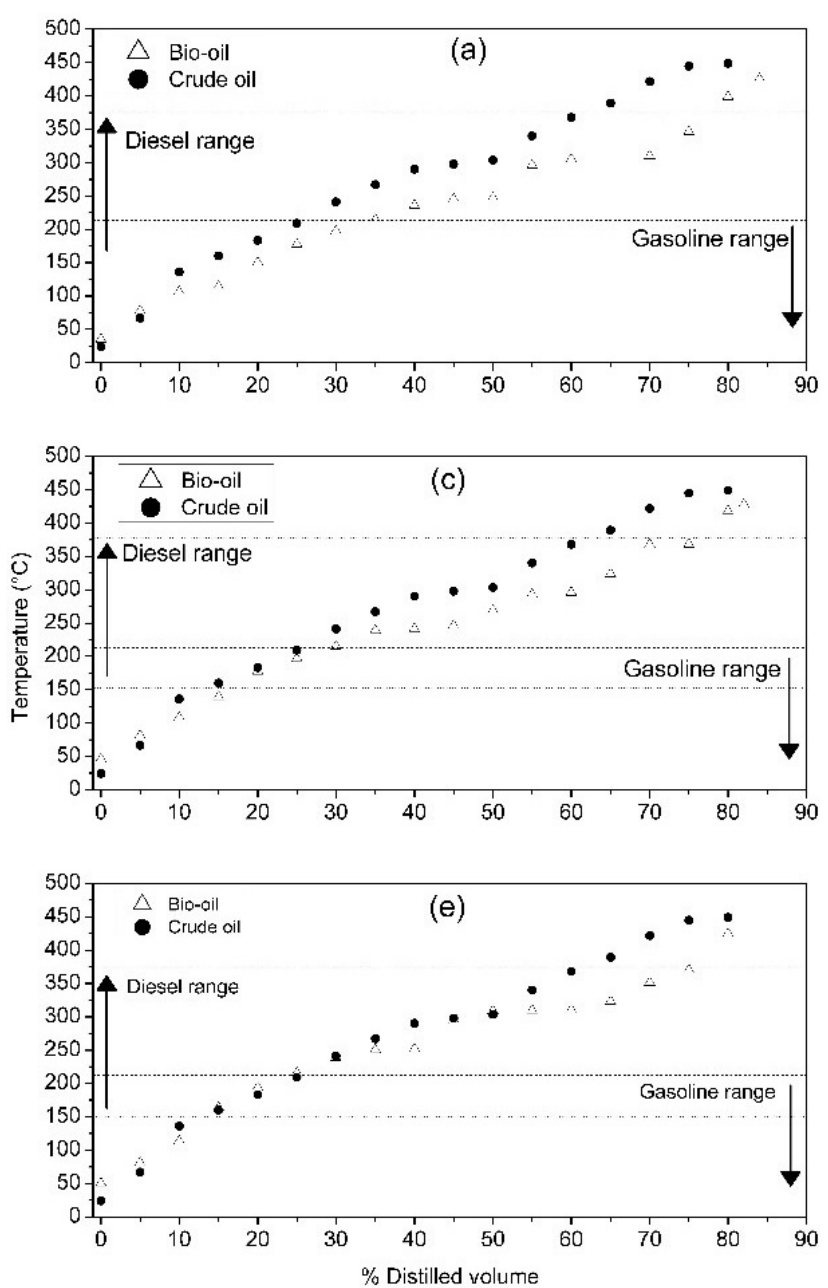

Figure 1. ASTM D86 distillation curves. where $\mathrm{CN}$ is the carbon number fraction, $\mathrm{AMW}$ is the average molecular weight of the respective n-alkane fraction and $\mathrm{N}$ is the number of fractions.

\section{RESULTS AND DISCUSSION}

\section{Distillation Curves of the Samples}

A comparison of the ASTM D86 distillation curve between each bio-oil sample (presented in Table 1) and the petroleum sample is shown in Figure 1. The letter in the upper part of each graph (a, b, c, d, e and f) corresponds to the samples indicated in Table 1 . Hence, it is ordered from higher to lower residence times. The volumes of the lighter phase of the biooils with boiling point below $150^{\circ} \mathrm{C}$, and the fraction that corresponds to the gasoline range $\left(220^{\circ} \mathrm{C}\right.$ - short dashed line on each graph) recovered, decrease with shorter residence times, as expected. Consequently, a greater amount of condensate is recovered in the diesel range between $150^{\circ} \mathrm{C}$ and $375^{\circ} \mathrm{C}$ (long dashed line on each graph).

For all bio-oil samples, there was a higher recovered volume of the heavier phase at temperatures
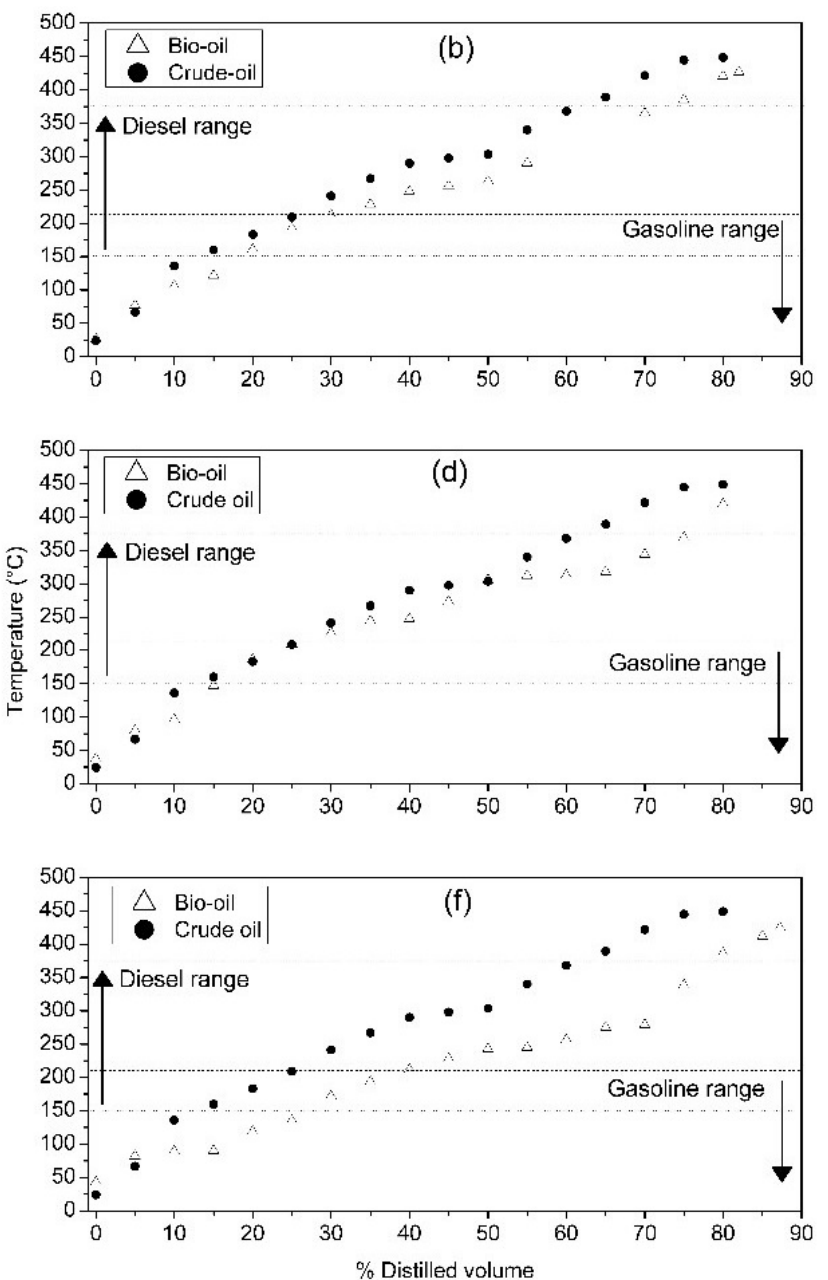
above $150^{\circ} \mathrm{C}$. The values for the percentage volume recovered corresponding to the gasoline range for samples (a) to (f) were $40 \%, 35 \%, 30 \%, 30 \%, 25 \%$ and $25 \%$, respectively. In the case of the diesel range, the values for the percentage volume recovered for samples (a) to (f) were $35 \%, 40 \%, 45 \%, 45 \%, 50 \%$ and $50 \%$, respectively. The temperature increased from 119 to $135^{\circ} \mathrm{C}, 114.1$ to $150.3^{\circ} \mathrm{C}, 121.9$ to $160^{\circ} \mathrm{C}$, 108.1 to $139.3^{\circ} \mathrm{C}, 96.2$ to $147^{\circ} \mathrm{C}$ and 113.5 to $163.6^{\circ} \mathrm{C}$, for samples (a) to (f), respectively, due to the absence of volatile components in these temperature ranges. In the case of the petroleum crude oil, the percentage of volume recovered in the gasoline range was $25 \%$ and in the diesel range it was $45 \%$. Only around $80 \%$ of the total volume was recovered.

The distillation curve relies on the type and quantity of compounds present in the mixture. A similarity between the curves is related to a high concentration of heavy compounds and boiling temperatures higher than $240^{\circ} \mathrm{C}$. Increasing lighter components in the sample with increasing residence was expected, changing the profile of the sample from the diesel to the gasoline range. Indeed, a reduction in the residence time (increased flow) in the pyrolysis of the residual frying oil generates compounds with a higher boiling point, and after $15 \%$ of recovered volume, the distinction between vapor temperatures is more evident. This is probably due to a lower degree of cracking of the bonds of the triacylglycerol molecules, with a greater number of compounds with higher carbon chain size, increasing the boiling point. The distillation curve for crude oil samples shows lower boiling points at the beginning of the distillation compared with the other samples and, after $60 \%$ of recovered volume, there is an increase in the highest boiling point. All experimental data related to ASTM D86 are reported in Table 3 as well as ASTM D1160 (already converted to ASTM D86) and the conversion to the true boiling point (TBP), which was used in the correlations. Points above $87.5 \%$ (90 and 95\%) in Table 3 were obtained by extrapolation. The conversion to TBP resulted in temperatures slightly below the ASTM at volume distilled below $50 \%$ and above it for volume distilled greater than $50 \%$. This behavior was expected since it is intrinsic from the method.

\section{Properties}

The results obtained for the density, molecular weight, ${ }^{\circ}$ API and VABP for all samples are shown in Figure 2. The density and distillation curve are the basic variables of the correlations used for the crude oil and its fractions. Figure 2(I) shows the density results obtained experimentally. The values are between 891 and $906 \mathrm{~kg} / \mathrm{m}^{3}$ for the bio-oil samples and decreased notably with shorter residence times. In comparison, the petroleum sample density was 898
Table 3. Conversion to true boiling point.

\begin{tabular}{|c|c|c|c|}
\hline \multirow[b]{2}{*}{ Sample } & \multirow[b]{2}{*}{$\begin{array}{c}\text { Distilled } \\
\text { Volume } \\
(\%)\end{array}$} & \multicolumn{2}{|c|}{ Temperature $\left({ }^{\circ} \mathrm{C}\right)$} \\
\hline & & $\begin{array}{c}\text { ASTM } \\
\text { D86 }\end{array}$ & $\begin{array}{c}\text { TBP } \\
\text { (API Method) } \\
\text { (API, 1997) }\end{array}$ \\
\hline \multirow{7}{*}{ a } & 0 & 43 & 20.2 \\
\hline & 10 & 89.5 & 69.8 \\
\hline & 30 & 171.7 & 165.9 \\
\hline & 50 & 242.7 & 245.8 \\
\hline & 70 & 279 & 288.6 \\
\hline & 90 & 466.2 & 486.5 \\
\hline & 95 & 532.5 & 562.3 \\
\hline \multirow{7}{*}{ b } & 0 & 35.4 & 13.1 \\
\hline & 10 & 106.2 & 87.0 \\
\hline & 30 & 197.1 & 192.1 \\
\hline & 50 & 246.8 & 250.0 \\
\hline & 70 & 310.2 & 321.1 \\
\hline & 90 & 496.2 & 517.6 \\
\hline & 95 & 573.9 & 606.8 \\
\hline \multirow{7}{*}{$\mathrm{c}$} & 0 & 26.9 & 5.2 \\
\hline & 10 & 105.8 & 86.6 \\
\hline & 30 & 212.5 & 208.0 \\
\hline & 50 & 263.4 & 267.0 \\
\hline & 70 & 365.2 & 378.4 \\
\hline & 90 & 497.1 & 518.6 \\
\hline & 95 & 545.7 & 576.5 \\
\hline \multirow{7}{*}{ d } & 0 & 46.1 & 23.1 \\
\hline & 10 & 108.1 & 89.0 \\
\hline & 30 & 215.5 & 211.1 \\
\hline & 50 & 268.6 & 272.3 \\
\hline & 70 & 367.5 & 380.8 \\
\hline & 90 & 497.7 & 519.2 \\
\hline & 95 & 558.8 & 590.5 \\
\hline \multirow{7}{*}{$\mathrm{e}$} & 0 & 37.3 & 14.9 \\
\hline & 10 & 96.2 & 76.7 \\
\hline & 30 & 226.2 & 222.2 \\
\hline & 50 & 305.6 & 310.3 \\
\hline & 70 & 343.6 & 355.9 \\
\hline & 90 & 542.9 & 566.2 \\
\hline & 95 & 640.1 & 678.1 \\
\hline \multirow{7}{*}{$\mathrm{f}$} & 0 & 50.3 & 27.0 \\
\hline & 10 & 113.5 & 94.6 \\
\hline & 30 & 238.9 & 235.3 \\
\hline & 50 & 309 & 313.8 \\
\hline & 70 & 351.7 & 364.3 \\
\hline & 90 & 557.7 & 581.6 \\
\hline & 95 & 662.4 & 702.1 \\
\hline \multirow{7}{*}{$\mathrm{g}$} & 0 & 24.3 & 2.8 \\
\hline & 10 & 136.1 & 118.1 \\
\hline & 30 & 241.0 & 237.4 \\
\hline & 50 & 303.4 & 308.0 \\
\hline & 70 & 421.5 & 437.2 \\
\hline & 90 & 536.9 & 559.9 \\
\hline & 95 & 580.7 & 614.1 \\
\hline
\end{tabular}

$\mathrm{kg} / \mathrm{m}^{3}$. Furthermore, the values are slightly higher than those obtained in other studies reported in the literature (Stedile et al., 2015; Yigezu and Muthukumar, 2014; Hassen-Trabelsi et al., 2013).

Figure 2(II) shows the molecular weights for all samples, obtained using the three methods in Table 1. Since the Pedersen and Twu correlations are designed for petroleum, they provided similar results for the 


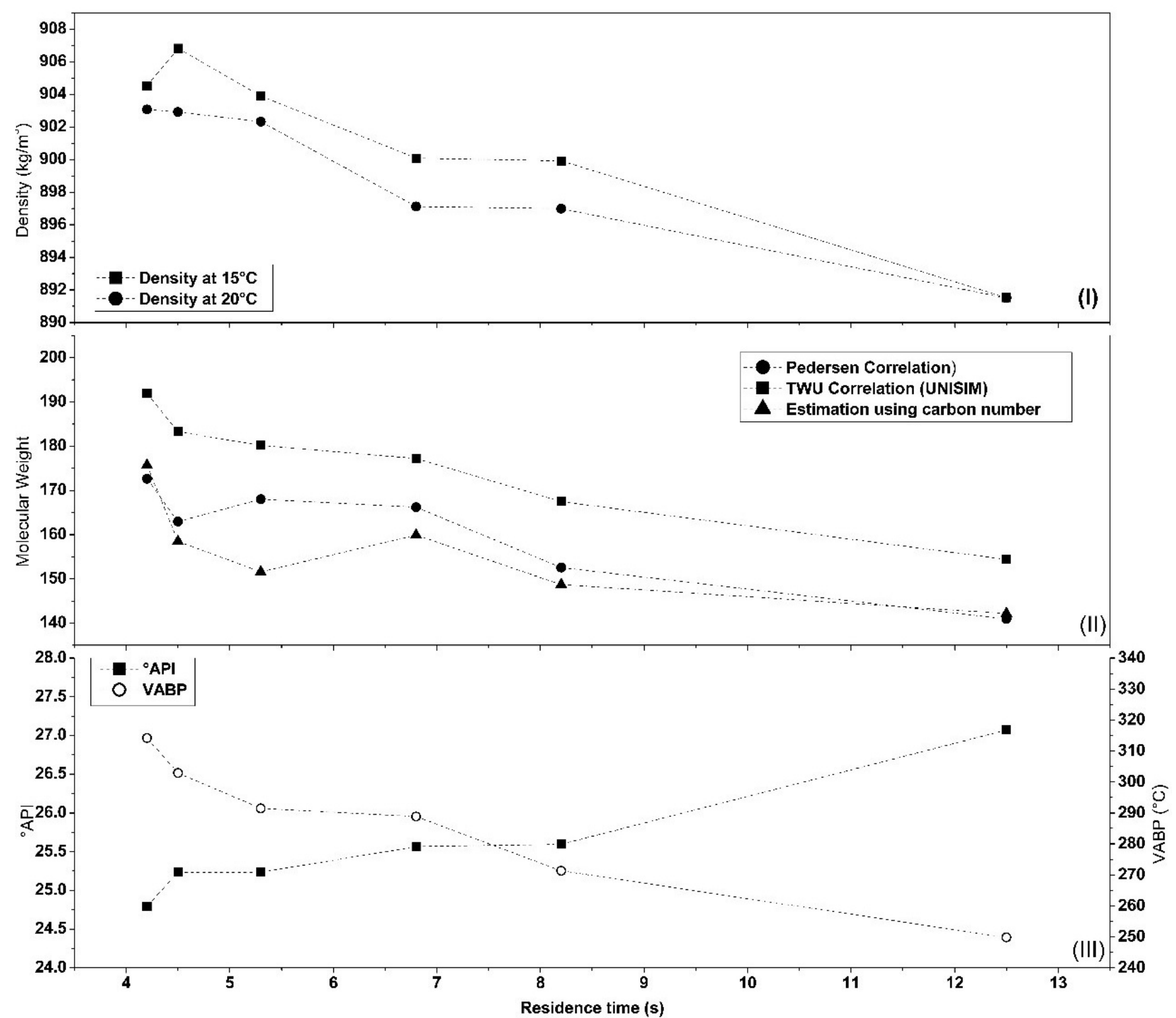

Figure 2. Density, MW, ${ }^{\circ} \mathrm{API}$ and VABP values for all bio-oil samples (the dashed line has the purpose to facilitate data visualization).

crude oil sample (198.4 and 199.5, respectively). However, there was a notable difference between the values for the two correlations for all bio-oil samples. Concerning bio-oil samples, molecular weight tends to increase with higher flow rates (shorter residence times) in the thermal cracking process. This behavior was expected, since with shorter residence times the thermal cracking reactions do not occur.

The results for the API gravity and the volumetric average boiling point (VABP) are shown in Figure 2(III). The ${ }^{\circ}$ API values for the bio-oils were between 24.8 and 27.1, while for the crude oil the value was 25.9. Values of 19-27 correspond to heavy crude oils. The API gravity decreases with shorter residence times, due to the presence of heavier compounds. On the other hand, the VABP increases with a decrease in the residence times, because compounds with a larger carbon chain are formed with a faster passage of the feedstock through the pyrolysis reactor and the boiling point is higher. The crude oil VABP was 327.8 ${ }^{\circ} \mathrm{C}$, which was higher when compared with bio-oil samples.

Figure 3 shows the Watson characterization factor $\left(\mathrm{K}_{\mathrm{w}}\right)$, the refractive, iodine and acid indexes and the kinematic viscosity for all bio-oil samples. The values obtained for $\mathrm{K}_{\mathrm{W}}$ and the refractive index (RI) are shown in Figure 3(I). The $\mathrm{K}_{\mathrm{w}}$ values obtained with the two methods (Watson and Abbot correlations) are similar. Considering the crude oil groups proposed by Watson, samples (a) to (f) correspond to the alkylbenzene family, and samples (a), (b) and, (d) belong to this group according to the Abbot correlation calculated in 


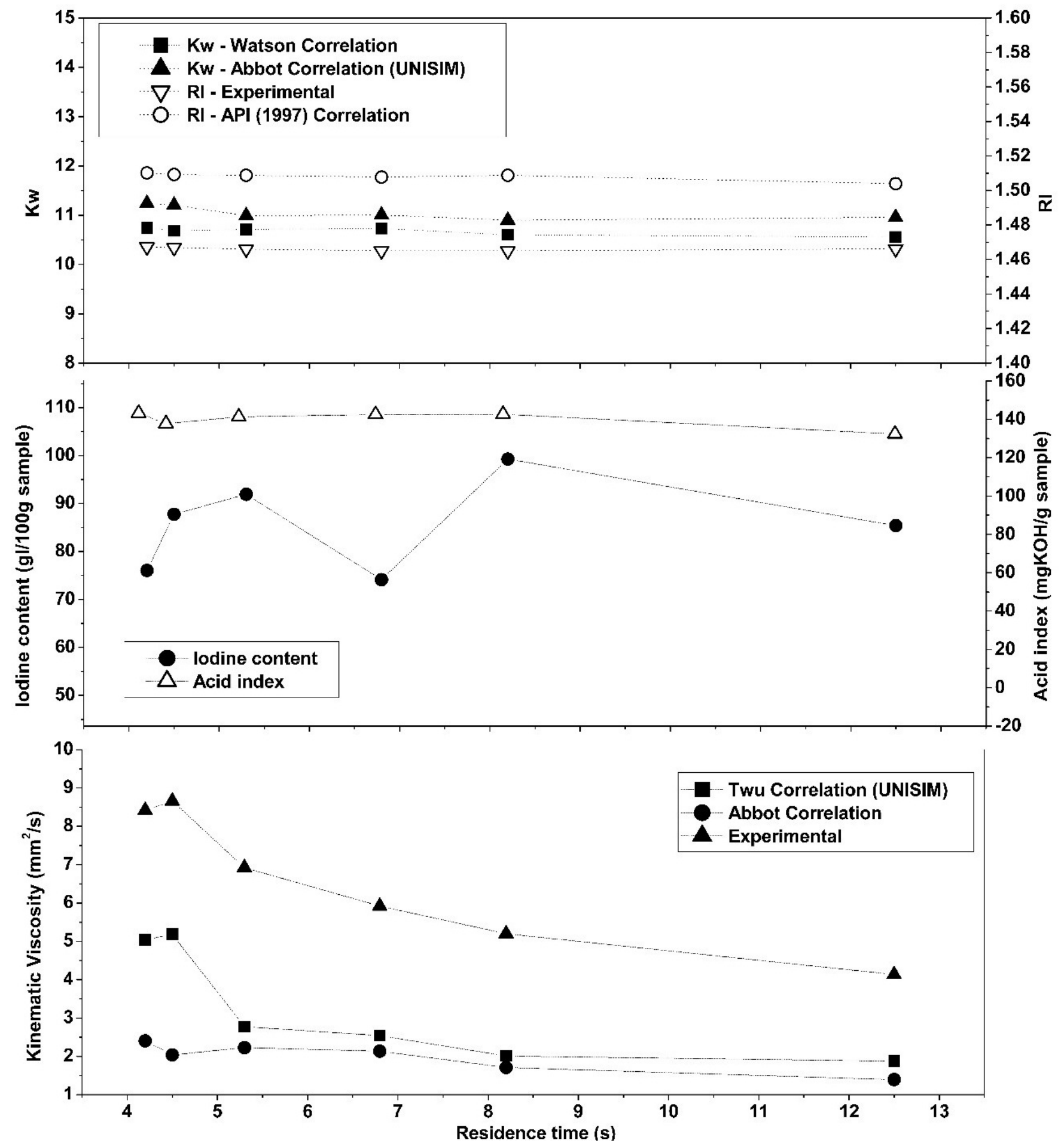

Figure 3. $\mathrm{K}_{\mathrm{w}}, \mathrm{RI}, \mathrm{II}, \mathrm{AI}$ and kinematic viscosity for all samples (the dashed line has the purpose to facilitate data visualization).

UNISIM. The $\mathrm{K}_{\mathrm{w}}$ values calculated by UNISIM for samples (c), (e) and (f), and also those for the petroleum sample calculated by both methods, correspond to the naphthenic family. These hydrocarbon groups were proposed by Watson for crude oil (Farah, 2012). The refractive index values are slightly different when we compare the results obtained from the experimental analysis and the correlations. There is a tendency toward an increase in the refractive index as the residence time decreases, due to the larger chemical structures of the compounds. No experimental result was obtained for the crude oil sample, since the apparatus was unable to read the experimental refractive index in this case.

The values obtained for the iodine and acid indexes are shown in Figure 3(II). The iodine index varies considerably and does not appear to have a strong 


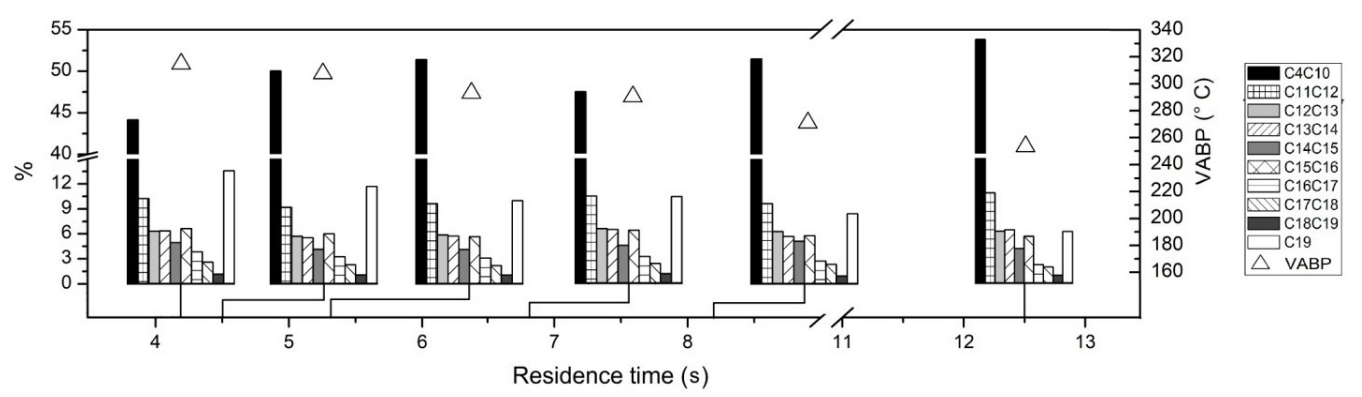

Figure 4. Carbon number distribution.

relation with the residence time. The values for the acid index for all bio-oil samples are very similar. In comparison with crude oil, all bio-oil samples had higher acid and iodine indexes. The lower values obtained for the bio-oils are undesirable, since they can lead to corrosion and instability, respectively. Thus, for bio-oil refining it is necessary to upgrade the bio-oil and make it suitable for processing. The acidity reduction or neutralization can be performed using potassium or sodium hydroxide or via an esterification reaction (Junming et al., 2009; Wisniewski et al., 2015; Moens et al., 2009), since the acidity is mainly due to the presence of carboxylic acids (Kraiem et al., 2016).

The olefins content can be reduced through hydrotreatment processes. The high content of renewable and light olefins indicates that these biooils could provide an important feedstock for the petrochemical industry (Sadrameli and Green, 2007).

Figure 3(III) shows the kinematic viscosity of the samples. For bio-oils this value is generally around $3.5 \mathrm{~mm}^{2} / \mathrm{s}$, as reported elsewhere (Stedile et al., 2015; Yigezu and Mothukumar, 2014; Lima et al., 2004). As in the case of the density, the kinematic viscosity tended to increase with a shorter residence time. The kinematic viscosity of the crude oil was higher in the case of the experimental data and the Abbot correlation. The results obtained with the Twu (UNISIM) and Abbot correlations were very close for almost all samples, while the values obtained with the experimental method were higher.

Figure 4 shows the number of carbon atoms in the carbon chain (volumetric percentage) versus VABP for the bio-oil and crude oil samples. All samples were processed with a lower input mass flow and, consequently, higher residence times, showing a higher quantity of lighter compounds (between $\mathrm{C}_{4}$ and $\left.\mathrm{C}_{12}\right)$. The amount of heavier compounds $(>\mathrm{C} 15)^{4}$ increased proportionally to the feed rate. Indeed, the VABP also increased with a larger quantity of compounds with more than 19 carbon atoms in the chain. The hydrocarbon size distributions of the bio-oil samples were close to that of the crude oil, indicating the possibility of refining and producing biofuels with properties like those of fossil fuels.

The content of oxygenated compounds in the biooil obtained from TG requires further investigation and is an ongoing research area (Meghan et al., 2017). Considering the co-processing in a refinery, the hydrotreatment process in the refinery could remove them and thus upgrade the properties of the bio-oils, since most of the oxygen atoms were removed during the thermal cracking, in the form of $\mathrm{CO}$ and $\mathrm{CO}_{2}$.

\section{CONCLUSIONS}

The results obtained from the distillation curves indicate that the bio-oil samples are complex mixtures of liquids and their behavior is similar to that of crude oil. Bio-oils contain a greater quantity of heavier compounds with boiling temperatures above $150^{\circ} \mathrm{C}$, which corresponds to the boiling range of diesel. This is related to the cracking conditions, since a short residence time tends to favor the formation of the heavier compounds in bio-oil. Since the triglyceride molecules undergo less bond cleavage, there are greater amounts of compounds with a higher carbon chain. The density, kinematic viscosity and VABP values are higher for the bio-oil produced with shorter residence times, due to the presence of components with higher carbon chain size. The bio-oil samples presented a high acid index, indicating that they are corrosive and restricting their possibilities for refining and use as a transport fuel, since they require an upgrading process. Alternative thermochemical processes such as hydrotreating, might be employed to deal with oxygenated compounds. Hydrotreating is widely used, especially for WCO conversion to biodiesel fractions, although it requires an expressive amount of hydrogen.

The presence of oxygenated compounds in bio-oil also defies a direct comparison with petroleum, the latter composed mainly by hydrocarbons with only a few heteroatoms. Nevertheless, the resemblance to petroleum curves in the distillation curves for biooil demonstrates the potential of the method as an important technique for predicting the physical and chemical properties of bio-oils. A knowledge of these properties is necessary for the design, scale up, and simulation process, and more research needs to be carried out to improve the methods and the results obtained. 


\section{ACKNOWLEDGMENTS}

The authors are grateful to the reviewers, the National Agency of Petroleum, Gas and Bio-fuels (ANP), CNPq (process number 308714/2016-4), and FURB for the financial support that made this research possible. This study was financed in part by the Coordenação de Aperfeiçoamento de Pessoal de Nível Superior - Brasil (CAPES) - Finance Code 001.

\section{REFERENCES}

Abbott, M.M., Kaufmann, T. G., Domash, L., A Correlation for Predicting Liquid Viscosities of Petroleum Fractions, The Canadian Journal of Chemical Engineering, 49, 379-384 (1971). https:// doi.org/10.1002/cjce.5450490314

API, Technical Data Book. American Petroleum Institute, Washington, DC. Technical Data BookPetroleum Refining (1993).

API, Technical Data Book. American Petroleum Institute. Technical Data Book-Petroleum Refining (1997).

Asomaning, J., Mussone, P., Bressler, B.C., Thermal cracking of free fatty acids in inert and light hydrocarbon gas atmospheres, Fuel, 126, 250-255 (2014). https://doi.org/10.1016/j.fuel.2014.02.069

Asomaning, J., Mussone, P., Bressler, B.C., Thermal deoxygenation and pyrolysis of oleic acid, $\mathrm{J}$ Anal Appl Pyrolysis, 105, 1-7 (2014). https://doi. org/10.1016/j.jaap.2013.09.005

Behrenbruch, P., Dedigama, T., Classification and characterization of crude oils based on distillation properties, Journal of Petroleum Science and Engineering 57, 166-180, (2007). https://doi. org/10.1016/j.petrol.2005.10.016

Bezergianni, S. et al., Hydrotreating of waste cooking oil for biodiesel production. Part II: Effect of temperature on hydrocarbon composition, Bioresource Technology, 101(19), pp. 7658-7660 (2010). https:// doi.org/10.1016/j.biortech.2010.04.043

Bezergianni, S., et al. Toward Hydrotreating of Waste Cooking Oil for Biodiesel Production. Effect of Pressure, H2/Oil Ratio, and Liquid Hourly Space Velocity, Industrial Engineering Chemistry Research, 50(7), pp 3874-3879 (2011). https://doi. org/10.1021/ie200251a

Bezergianni, S. et al., Catalyst Evaluation for Waste Cooking Oil Hydroprocessing, Fuel, 93, pp. 638-647 (2012). https://doi.org/10.1016/j. fuel.2011.08.053

Beims, R.F., Bertoli, S. L., Botton, V., Ender, L., Simionatto, E. L., Meier, H. F., Wiggers, V. R., Coprocessing of thermal cracking bio-oil at petroleum refineries, Brazilian Journal of Petroleum and Gas 11, 99-113 (2017). https://doi.org/10.5419/ bjpg2017-0009
Beims, R.F., Botton, V., Ender, L., Scharf, D.R., Simionatto, E.L., Meier, H.F., Wiggers, V.R., Effect of degree of triglyceride unsaturation on aromatics content in bio-oil, FUEL 217, pp. 175-184 (2018a). https://doi.org/10.1016/j.fuel.2017.12.109

Beims, R.F., Botton, V., Ender, L., Scharf, D.R., Simionatto, E.L., Meier, H.F., Wiggers, V.R., Experimental data of thermal cracking of soybean oil and blends with hydrogenated fat, Data in Brief 17, pp. 442-451 (2018b). https://doi.org/10.1016/j. dib.2018.01.054

Bergthorson, J.M., Thomson, M.J. A review of the combustion and emissions properties of advanced transportation biofuels and their impact on existing and future engines. Renewable and Sustainable Energy Reviews 42, 1393-1417 (2015). https://doi. org/10.1016/j.rser.2014.10.034

Bielansky, P., Weinert, A., Schönberger, C., Reichhold, A., A. Catalytic conversion of vegetable oils in a continuous FCC pilot plant, Fuel Processing Technology, 92, 2305-2311 (2011). https://doi. org/10.1016/j.fuproc.2011.07.021

Botton, V., Riva, D., Simionatto, E.L., Wiggers, V.R., Ender, L., Meier, H.F., Barros, A.A.C., Thermocatalytic cracking of the mixture of used frying oil - textile stamping sludge for the production of oil with low acidity index,, Quim. Nova 35, 677-682 (2012). https://doi.org/10.1590/S010040422012000400004

Botton, V., Souza, R.T., Wiggers, V.R., Scharf, D.R., Simionatto, E.L., Ender, L., Meier, H.F., Thermal cracking of methyl esters in castor oil and production of heptaldehyde and methyl undecenoate, Journal of Analytical and Applied Pyrolysis 121, 387-393 (2016). https://doi.org/10.1016/j.jaap.2016.09.002

Bridgwater, A.V., Review of fast pyrolysis of biomass and product upgrading, Biomass Bioenergy 38, 68-94 (2012). https://doi.org/10.1016/j. biombioe.2011.01.048

Bruno, T.J., Ott, L.S., Lovestead, T.M., Huber, M.L., The composition explicit distillation curve technique: Relating chemical analysis and physical properties of complex fluids, Journal of Chromatography A 1217, 2703-2715 (2010). https://doi.org/10.1016/j.chroma.2009.11.030

Butler, E., Devlin, G., Meier, D., McDonnell, K., A review of recent laboratory research and commercial developments in fast pyrolysis and upgrading, Renewable and Sustainable Energy Reviews 15, 4171-4186 (2011). https://doi. org/10.1016/j.rser.2011.07.035

Buzetzki, E., Sidorová, K., Cvengrošová, Z., Cvengroš, J., Effects of oil type on products obtained by cracking of oils and fats, Fuel Process Technol, 92, 2041-2047, (2011) https://doi.org/10.1016/j. fuproc.2011.06.005 
Cardoso, C.R., Miranda, M.R., Santos, K.G., Ataíde, C.H., Determination of kinetic parameters and analytical pyrolysis of tobacco waste and sorghum bagasse, Journal of Analytical and Applied Pyrolysis, 92, 392-400 (2011). https://doi. org/10.1016/j.jaap.2011.07.013

Cheng, D., Wang, L., Shahbazi, A., Xiu, S., Zhang, B., Characterization of the physical and chemical properties of the distillate fractions of crude bio-oil produced by the glycerol-assisted liquefaction of swine manure, Fuel 130, 251-256 (2014). https:// doi.org/10.1016/j.fuel.2014.04.022

Dai, K., Bergot, A., Liang, C., Xiang, W.N., Huang, Z., Environmental issues associated with wind energy - A review, Renewable Energy, 75, 911-921 (2015). https://doi.org/10.1016/j.renene.2014.10.074

Doronin, V.P., Lipin, P.V., Potapenko, O.V., Arbuzov, A.B., Sorokina, T.P.. Features of Combined Conversion of Naphthenic Hydrocarbons and Fatty Acids under Catalytic Cracking Conditions. Petroleum Chemistry, 56, 745-752 (2016). https:// doi.org/10.1134/S096554411608003X

Fahim, M.A., Al-Sahhaf, T.A., Elkilani, A.S., Fundamentals of petroleum refining, first ed., Elsevier (2010).

Farah, M.A., Petróleo e Seus Derivados: Definição, Constituição, Aplicação, Especificações e Características de Qualidade, first ed., LTC (2012).

Frainer, B.L.M., Wiggers, V.R., Sharf, D.R., Meier, H.F., Ender, L., Simionatto, E.L., Thermal Cracking of Frying Oil: A Proposal for a Kinetic Mechanism Based on Groups of Compounds, American Institute of Chemical Engineers, editor. 2014 Annual Meeting; November 20 ${ }^{\text {th }}$, 2014; Atlanta, GA. American Institute of Chemical Engineers (2014).

Gaurav, N., Sivasankari, S., Kiran, G.S., Ninawe, A., Selvin, J., Utilization of bioresources for sustainable biofuels: A Review, Renewable and Sustainable Energy Reviews 73, 205-214 (2017). https://doi.org/10.1016/j.rser.2017.01.070

Goyal, H.B., Seal, D., Saxena, R.C., Bio-fuels from thermochemical conversion of renewable resources: A review, Renewable and Sustainable Energy Reviews 12, 504-517, (2008). https://doi. org/10.1016/j.rser.2006.07.014

Harries, M.E., McDonald, A.G., Bruno, T.J., Measuring the distillation curves of non-homogeneous fluids: Method and case study of two pyrolysis oils, Fuel 204, 23-27 (2017). https://doi.org/10.1016/j. fuel.2017.04.066

Hassen-Trabelsi,A.B., Kraiem, T., Naoui, S., Belayouni, H., Pyrolysis of waste animal fats in a fixed-bed reactor: production and characterization of bio-oil and bio-char, Waste Manage 34, 210-8 (2013). https://doi.org/10.1016/j.wasman.2013.09.019
Ho, D.P., Ngo, H.H., Guo, W., A mini review on renewable sources for biofuel. Bioresource Technology, 169, 742-749 (2014). https://doi. org/10.1016/j.biortech.2014.07.022

Huber, G.W, Corma, A. Synergies between Bio- and Oil Refineries for the Production of Fuels from Biomass. Angew. Chem. Int. Ed. 46, 7184-7201 (2007). https://doi.org/10.1002/anie.200604504

Jayasinghe, P., Hawboldt, K., A review of bio-oils from waste biomass: Focus on fish processing waste, Renewable and Sustainable Energy Reviews 16, 798-821, (2012). https://doi.org/10.1016/j. rser.2011.09.005

Junming, X., Guomin, X., Yonghong, Z., Jianchun, J., Production of biofuels from high-acid-value waste oils, Energy Fuels, 25, 4638-4642 (2011). https:// doi.org/10.1021/ef2006723

Junming, X., Jianchun, J., Jiaping, Z., Thermochemical conversion of triglycerides for production of drop-in liquid fuels, Renewable and Sustainable Energy Reviews 58, 331-340 (2016). https://doi. org/10.1016/j.rser.2015.12.315

Junming, X., Jianchun, J., Yanju, L., Jie, C., Liquid hydrocarbon fuels obtained by the pyrolysis of soybean oils, Bioresource Technology 100, 4867-4870 (2009). https://doi.org/10.1016/j. biortech.2009.04.055

Kraiem, T., Hassen, A.B., Belayouni, H., Jeguirim, M., Production and characterization of bio-oil from the pyrolysis of waste frying oil, Environ. Sci. Pollut. Res. 24, 9951-9961 (2016). https://doi.org/10.1007/ s11356-016-7704-z

Kubatova, J. et al. Triacylglyceride thermal cracking: pathways to cyclic hydrocarbons, Energy Fuel, 26, pp. 672-685 (2012) https://doi.org/10.1021/ ef $200953 \mathrm{~d}$

Lima, D.G., Soares, V.C.D., Ribeiro, E.B., Carvalho, D.A., Cardoso, E.C.V., Rassi, F.C., Mundim, K.C., Rubim, J.C., Suarez, P.A.Z., Diesel like fuels obtained by pyrolysis of vegetable oils, Journal of Analytical and Applied Pyrolysis 71, 987-996 (2004). https://doi.org/10.1016/j.jaap.2003.12.008

Lu, L., Kejing, Q., Junming, X., Fusheng, L., Shiwei, L., Shitao, Y., Congxia, X., Baoquan, Z., Xiaoping, G., Liquid hydrocarbon fuels from catalytic cracking of rubber seed oil using USY as catalyst, Fuel 123 (2014) 189-193. https://doi.org/10.1016/j. fuel.2014.01.061

Mancio, A.A., Costa, K.M.B., Ferreira, C.C., Santos, M.C., Lhamas, D.E.L., Mota, S.A.P., Leão, R.A.C., Souza, R.O.M.A., Araújo, M.E., Borges, L.E.P., Machado, N.T., Thermal catalytic cracking of crude palm oil at pilot scale: Effect of the percentage of $\mathrm{Na} 2 \mathrm{CO} 3$ on the quality of biofuels, Industrial Crops and Products 91 (2016) 32-43. https://doi. org/10.1016/j.indcrop.2016.06.033 
Meier, H.F., Wiggers, V.R., Zonta, G.R., Scharf, D.R., Simionatto, E.L., Ender, L., A kinetic model form thermal cracking of waste cooking oil based on chemical lumps, Fuel 144, 50-9 (2015). https://doi. org/10.1016/j.fuel.2014.12.020

Moens, L., Black, S.K., Myers, M.D., Czernik, S., Study of the Neutralization and Stabilization of a Mixed Hardwood Bio-Oil, Energy \& Fuels 23, 2695-2699 (2009). https://doi.org/10.1021/ ef8009266

Naik, S.N., Goud, V.V., Rout, P.K., Dalai, A.K., Production of first and second generation biofuels: A comprehensive review, Renewable and Sustainable Energy Reviews 14, 578-97, (2010). https://doi. org/10.1016/j.rser.2009.10.003

Ott, L.S., Smith, B.L., Bruno, T., Advanced distillation curve measurements for corrosive fluids: Application to two crude oils, Fuel 87, 3055-3064 (2008a). https://doi.org/10.1016/j.fuel.2008.04.032

Ott, L.S., Smith, B.L., Bruno, T., Advanced distillation curve measurement: Application to a bio-derived crude oil prepared from swine manure, Fuel 87, 3379-3387, (2008b). https://doi.org/10.1016/j. fuel.2008.04.038

Pedersen, K.S., Thomassen, P., Fredenslund, A.A., Thermodynamics of petroleum mixtures containing heavy hydrocarbons, Taylor \& Francis, New York, 1, 137-152 (1989).

Periyasamy, B., Reaction pathway analysis in thermal cracking of waste cooking oil to hydrocarbons based on monomolecular lumped kinetics, Fuel 158, 479-487 (2015). https://doi.org/10.1016/j. fuel.2015.05.066

Quelhas, A.D., Passos, C.N., Lage, D.F..S., Abadie, E., Sousa, E.C.M., Cordeiro, F.G., Krahl, I.M., Farah, M.A., Araújo, M.A.S., Brasil, N.I., Camargo, P.R.C., Pinto, P.R.C., Processamento de Petróleo e Gás, second ed., LTC - Livros Técnicos e Científicos Ltd., (2014).

Sadrameli, S.M., Green, A.E.S., Systematics of renewable olefins from thermal cracking of canola oil. J. Anal. Appl. Pyrolysis 78, 445-451 (2007). https://doi.org/10.1016/j.jaap.2006.12.010

Shirazi, Y., Viamajala, S., Varanasi, S., High-yield production of fuel- and oleochemical-precursors from triacylglycerols in a novel continuousflow pyrolysis reactor, Applied Energy 179, 755-764 (2016). https://doi.org/10.1016/j. apenergy.2016.07.025

Speight, J.G., The chemistry and technology of petroleum fourth ed, CRC Press (2006). https://doi. org/10.1201/9781420008388

Stedile, T., Ender, L., Meier, H.F., Simionatto, E.L., Wiggers, V.R., Comparison between physical properties and chemical composition of bio-oils derived from lignocellulose and triglyceride sources, Renewable and Sustainable Energy Reviews 50, 92-108 (2015). https://doi. org/10.1016/j.rser.2015.04.080

Twu, C.H., An internally consistent correlation for predicting the critical properties and molecular weights of petroleum and coal-tar liquids, Fluid Phase Equilibria 16, 137-150 (1984). https://doi. org/10.1016/0378-3812(84)85027-X

Twu, C.H., Generalized Method for Predicting Viscosities of Petroleum Fractions, AIChE Journal, 32, 2091-2094 (1986). https://doi.org/10.1002/ aic. 690321221

Wauquier, J. P., Crude oil. Petroleum products, Process flowsheets, Paris: Editions Technip (1995).

Wiggers, , V.R., Wisniewski Jr., A., Madureira, L.A.S., Barros, A.A.C., Meier, H.F., Biofuels from waste fish oil pyrolysis: Continuous production in a pilot plant, Fuel 88, 2135-2141 (2009a). https://doi. org/10.1016/j.fuel.2009.02.006

Wiggers, V.R., Meier, H.F., Wisniewski, A., Barros, A.A.C., Maciel, M.R.W., Biofuels from continuous fast pyrolysis of soybean oil: A pilot plant study. Bioresource Technology 100, 6570-6577 (2009b). https://doi.org/10.1016/j.biortech.2009.07.059

Wiggers, V.R., Beims, R.F., Ender, L., Simionatto, E.L., Meier, H.F., Renewable Hydrocarbons from Triglyceride's Thermal Cracking, In: Jacob-Lopes E, Zepka LQ, editors. Biofuel, INTECH, USA, (2017). https://doi.org/10.5772/65498

Wiggers, V.R., Zonta, G.R., França, A.P., Scharf, D.R., Simionatto, E.L., Ender, L., Meier, H.F., Challenges associated with choosing operational conditions for triglyceride thermal cracking aiming to improve biofuel quality, Fuel 107, 601-608, (2013). https:// doi.org/10.1016/j.fuel.2012.11.011

Wisniewski Jr., A., Wosniak, L., Scharf, D.R., Wiggers, V.R., Meier, H.F., Simionatto, E.L., Upgrade of Biofuels Obtained from Waste Fish Oil Pyrolysis by Reactive Distillation, J. Braz. Chem. Soc. 2, 224-232 (2015). https://doi.org/10.5935/01035053.20140251

Xiu, S., Shahbazi, A., Bio-oil production and upgrading research: a review. Renewable Sustainable Energy Reviews 16, 4406-14 (2012). https://doi. org/10.1016/j.rser.2012.04.028

Yang, Z., Kumar, A., Huhnke, R.L., Review of recent developments to improve storage and transportation stability of bio-oil, Renewable and Sustainable Energy Reviews 50, 859-870 (2015). https://doi. org/10.1016/j.rser.2015.05.025

Yigezu, Z.D., Muthukumar, K., Catalytic cracking of vegetable oil with metal oxides for biofuel production, Energy Conversion and Management, 84, 326-333 (2014). https://doi.org/10.1016/j. enconman.2014.03.084 
Zhang, L., Liu, R., Yin, R., Mei, Y., Upgrading of bio-oil from biomass fast pyrolysis in China: a review, Renewable Sustainable Energy Reviews 24, 66-72 (2013). https://doi.org/10.1016/j. rser.2013.03.027
Zhang, L., Xu, C.C., Champagne, P., Overview of recent advances in thermo-chemical conversion of biomass, Energy Conversion and Management, 51, 969-982 (2010). https://doi.org/10.1016/j. enconman.2009.11.038 
